extent of the inversion is defined. Such inversions tend to prevent upward convection and the formation of rain is hindered. Complete observations of halo would be of material assistance. At de Bilt in 1922, rain followed halo in 70 per cent. of cases of halo observations, and only 70 out of 200 rain-days were not preceded by halo observations somewhere in Holland.

The anniversary dinner was held on the evening of April 22. After the toast of the King, patron of the Society, had been enthusiastically honoured, $\mathrm{Mr} . \mathrm{H}$. Mellish proposed the toast of The Services, and Capt. H. P. Douglas, Hydrographer of the Navy, responded. He spoke of the work which is now being done in the
Navy in the investigation of the upper air by pilot balloons and registering balloons. Sir Philip Sassoon, M.P., Under-Secretary of State for Air, proposed the toast of the Royal Meteorological Society. He referred to some of the events in the history of the Society, and paid a tribute to the aid which meteorologists had been able to send to the Airship R33, in the shape of weather reports and directions for the best course to be taken, on the occasion of its recent break-away in a gale from its mooring-mast at Pulham. The president responded to this toast. Sir Napier Shaw proposed the toast of International Meteorology, and Prof. E. van Everdingen responded.

R. C.

\title{
The British Science Guild.
}

THE annual meeting of the British Science Guild was held in the Salters' Hall on 'Tuesday, April $2 x$, the chair being taken by the Right Hon. Lord Askwith, president of the Guild.

Reviewing the work of the Guild, the chairman directed attention particularly to its co-ordinative functions, linking together the operations of many different bodies, and to its efforts to bridge the gulf between men of science and the general public. Reference was made to the issue of the revised edition of the Catalogue of British Scientific and Technical Books, which now contains more than 9500 titles of books, and should prove most valuable to students, libraries, and manufacturers. Methods of obtaining "Science Publicity" are being considered, but this demands the co-operation of leading scientific and technical societies. A new feature has been the formation of six standing committees (National Security, Parliamentary, Health, Research and Industry, Finance, and General Purposes).

An address emphasising the need of increasing knowledge of science among the public, and the application of scientific method to public affairs, was delivered by Sir William Bragg, who pointed out the contrast between the marvellously rapid development of scientific data, and the meagre facilities for letting the public know what was being done on their behalf. The forty millions of people in the British Isles are living on the direct application of science, and they should know what science has done, and what it might do in the future. It is unfortunate that scientific men, who spend their days in wresting information from Nature in the laboratory, have not as a rule the supplementary gift of conveying scientific information in a popular form. Publicity for science is needed. If, as it is hoped, a proper organisation for publicity in scientific matters could be created, there should be at its head a scientific literary man, and behind it funds sufficient to tide over the first period of its existence.

Sir Arthur Newsholme, speaking as chairman of the Health Committee, said that the average life of a child born to-day is some Io to 12 years longer than it was 30 to 40 years ago. This is due to a better knowledge of the laws of health. What should be investigated are the causes of evils rather than their alleviation-as illustrated by the millions of headache powders and similar nostrums sold. Attention has been directed by the Health Committee to two defects in the Births and Deaths Registration Bill now before Parliament. There is no valid verification of the fact of death, and the certificate. of death should be regarded as confidential and lodged with the registrar and not handed to the nearest relative.

Major the Hon. H. Fletcher Moulton (chairman of the Research and Invention Committee) pointed out that in regard to industry there is a gap similar to that remarked on by Sir William Bragg in connexion with publicity. Manufacturers of Great Britain are sometimes blamed for not availing themselves more freely of the results of scientific researches. There is, however, a gulf between the man working in the laboratory and the business man. An intermediary, who could demonstrate to the latter how he would benefit from the application of science, is needed. It is in this intermediate stage that Germany has made such rapid progress.

\section{Excavations at Cresswell Crags, Derbyshire.}

$\mathrm{A}^{\mathrm{T}}$ T a meeting of the Royal Anthropological Institute held on April 2I, Mr. A. Leslie Armstrong read a paper entitled " Recent Excavations on Palæolithic Sites at Cresswell Crags, Derbyshire," describing excavations which had been carried out by him under a Joint Committee of the British Association and the Royal Anthropological Institute. The two important sites of Upper Palæolithic date under investigation consist of a rock shelter and a cave respectively. The former, excavated between June and October I924, is situated in front of Mother Grundy's Parlour, the last cave of the Cresswell group excavated by Sir William Boyd Dawkins and the late Rev. J. M. Mills in I879. This proved to - be an undisturbed stratified deposit with a Palæolithic relic bed 2 feet 6 inches thick. The lowest stratum yielded implements of quartzite which, from evidence afterwards obtained in the cave site, are probably referable to Mousterian times. Overlying this was a rich deposit from which flint implements, bone tools, and three pieces of engraved bone were recovered. The latter are believed to reptesent bison, reindeer, and rhinoceros, but all are fragmentary. At the lowest level of this layer was a hearth formed in a hollow scooped out in the basement bed and ringed around with flat stones, on edge, just as Boy Scouts build a fireplace to-day. The area around the fire proved the most prolific in antiquities. The flint implements from that level are late Aurignacian in general character, those from the top of the deposit are early Tardenoisian, and those from the intervening layer reveal a gradual development in style and technique from one culture to the other.

The second site dealt with was the cave known locally as the Pin Hole. Excavations in September last revealed that the examination made by Mills fifty years ago had extended to the first seven yards only, and that the remainder of the cave was practically undisturbed. Through the generosity of the Percy Sladen Memorial Fund Trustees and the kindness of

NO. 2896 , VOL. I I 5$]$ 